\title{
Membumikan Gagasan Mesianik: Upaya Rekontekstualiasi Mesianisme dalam Bingkai Kehidupan Bersama
}

\author{
Yushak Soesilo \\ Sekolah Tinggi Teologi Intheos Surakarta \\ yushak@sttintheos.ac.id
}

\begin{abstract}
This paper aims to propose a recontextualization of messianic ideas within the framework of living together in Indonesia. The method used is the interpretation of the three messianic texts in the book of Isaiah. The conclusion of this study resulted in the idea that reading of the Old Testament texts, especially those related to messianic themes, does not always have to be understood through reading the New Testament because the discovery of rich meaning occurs when the Old Testament text is read in its own context.
\end{abstract}

Keywords: book of Isaiah; messianic; nationalism; Old Testament

Abstrak: Makalah ini bertujuan untuk mengajukan sebuah rekontekstualisasi ide mesianik dalam bingkai kehidupan bersama di Indonesia. Metode yang digunakan adalah interpretasi atas tiga teks mesianik dalam kitab Yesaya. Simpulan dari kajian ini menghasilkan gagasan agar pembacaan teks Perjanjian Lama, khususnya terkait tema mesianik, tidak selalu harus dipahami melalui pembacaan Perjanjian Baru, karena penemuan makna yang kaya terjadi ketika teks Perjanjian Lama dibaca dalam konteksnya sendiri.

Kata kunci: kitab Yesaya; mesianik; nasionalisme; Perjanjian Lama;

\section{Pendahuluan}

Dalam suatu kesempatan perkuliahan saya membuka dengan pertanyaan kepada mahasiswa, "menurut kalian apa itu mesias?" Seperti yang sudah saya duga bahwa mereka memberikan jawaban yang pada dasarnya sama saja satu dengan yang lainnya. Mesias dipahami sebagai sang juru selamat yang menebus dosa manusia, yang tentu saja tokoh yang dimaksudkan adalah Yesus Kristus. Jawaban tersebut tidaklah salah, namun itu menunjukkan bahwa konsep mesianis selalu dipahami dalam pemaknaan tunggal dan bersifat transendental. Padahal konsep mesianis sendiri tidaklah merupakan gagasan khas dari Alkitab. Setiap bangsa atau kebudayaan bahkan memiliki pengharapan mesianiknya masing-masing. Orang Jawa misalnya terkenal dengan pengharapan mesianik tentang Ratu Adil. Implikasi dari memahami konsep mesianis secara beku dan kaku tersebut adalah menjadikan konsep tersebut tidak dapat berdialog dengan realitas kehidupan bersama sebagai sebuah bangsa, bahkan akan condong memisahkan antara pergumulan yang dianggap dalam wilayah rohani dan jasmani.

Dalam makalah ini saya mencoba membuka kemungkinan untuk dapat mengkonteksulangkan ide mesianis untuk selalu relevan dengan realitas hidup bersama. Sebagai pijakan, saya mengambil tiga teks mesianik dalam kitab Yesaya, yaitu Yesaya 11:1-10; 52:13-53:12; 61:1-11 untuk melihat keragaman gagasan mesinik di dalamnya. Kitab Yesaya saya pilih oleh 
karena kitab ini meliputi periode yang sangat panjang, yaitu era monarki Yehuda, era pembuangan, dan era pasca pembuangan. Ketiga teks tersebut saya ambil dari masing-masing periode tersebut. Teks-teks tersebut secara singkat dikaji dengan pendekatan ideologi. Buku "An Introduction to the Hebrew Bible: A Tematic Approach" dari Sandra L. Gravett membantu saya memberikan gambaran ideologi yang berkembang dan populer pada masing-masing periode sehingga membantu untuk mengenali pengharapan seperti apakah yang sebenarnya ada di balik teks tersebut.

\section{Gagasan Mesianis dalam Kitab Yesaya}

\section{Yesaya 11:1-10}

Yesaya 11:1-10 menyampaikan pengharapan mesianik melalui metafor munculnya cabang dari tunggul Isai dan tunas yang mucul dari akar Isai. Mesias digambarkan sebagai sang tunas yang akan memerintah dalam kebenaran dan keadilan yang hasil dari pemerintahannya tersebut adalah keadaan damai sejahtera. Munculnya gagasan ini tidak terlepas dari situasi monarki Yehuda yang mengalami pasang surut baik oleh permasalahan yang timbul dari dalam maupun luar negeri. Sang mesias tersebut datang untuk menjadi solusi bagi permasalahan kontekstual yang dialami oleh umat.

Penggunaan metafor tunggul atau akar Isai tentu tidak terlepas bahwa sang mesias yang diharapkan adalah seorang raja. Pengharapan akan sosok raja yang menjadi mesias tidak terlepas dari ideologi yang berkembang pada saat itu, yaitu ideologi Raja-Sion. Ideologi RajaSion adalah ideologi yang dibangun oleh wangsa Daud dalam perjalanan kekuasaannya. Ideologi ini dipahami dalam relasi tiga kaki, Yhwh - Raja - Sion (Bait Suci). ${ }^{1}$ Raja dipandang sebagai sosok yang istimewa, yang bahwa digambarkan hampir seperti Allah sendiri, lengkap dengan kuasa dan kekuatan ilahinya. Sebagaimana Allah yang mengatur kosmos, maka raja adalah sebagai pengatur ketertiban negara. Oleh karena itu, ideologi Sion memanfaatkan teologi penciptaan dalam rangka menarasikan pentingnya peran raja bagi umat. Di dalam ayat 6-8 ada penggambaran situasi pada awal penciptaan, di mana seluruh ciptaan hidup bersama dengan damai. Situasi tersebut digunakan untuk menggambarkan hasil dari pemerintahan sang raja-mesianik tersebut. Memang ada kesulitan yang muncul ketika menghubungkan ideologi Raja-Sion, yang menempatkan wangsa Daud sebagai satu-satunya sosok raja yang legitim, dengan istilah "cabang dari tunggul Isai dan tunas dari akarnya," yang mengesankan bahwa raja tersebut adalah di luar wangsa Daud. Mengenai kesulitan tersebut, Sumner berpendapat bahwa istilah tersebut muncul sebagai penilaian negative terhadap pemerintahan wangsa Daud selama ini, dan dibutuhkan penyegaran, meskipun tidak harus sosok raja yang berasal dari luar wangsa Daud. ${ }^{2}$ Dengan demikian, gagasan raja-mesias dari wangsa Daud tetap terpelihara dalam konteks monarki Yehuda.

Keadaan yang begitu damai sebagaimana yang disebutkan di ayat 6-8, yang meskipun bersumber dari narasi kehidupan pada awal penciptaan tetap terasa sangat utopis. Bagaimana bisa binatang buas, yang memangsa binatang lainnya, dapat hidup bersama dengan binatang yang biasa menjadi mangsa binatang buas? Dalam sebuah diskusi saya dengan Robert Setio ${ }^{3}$,

\footnotetext{
${ }^{1}$ Sandra L. Gravett et al., An Introduction to the Hebrew Bible: A Tematic Approach (Louisville-London: Westminster John Knox Press, 2008), 324-325.

${ }^{2}$ Stephen T. Sumner, "The Genealogy and Theology of Isaiah 11:1," Vetus Testamentum 68, no. 4 (September 14, 2018): 643-659, accessed December 13, 2020, https://brill.com/view/journals/vt/68/4/articlep643_7.xml.

${ }^{3}$ Dosen bidang Biblika Perjanjanjian Pertama Fakultas Teologi UKDW Yogyakarta
} 
beliau mengatakan hal itu bisa saja terjadi jika semua binatang tersebut mendapatkan makanannya masing-masing. Saya sepakat dengan pendapat tersebut. Di dalamnya menyiratkan gagasan keadilan, bahwa semuanya mendapatkan sesuai bagiannya. Hal itu juga selaras dengan yang dikatakan oleh Brueggemann bahwa raja-mesianik tersebut menjalankan peran judicial. ${ }^{4}$ Sebagaimana disebutkan dalam ayat 3b-5, raja tersebut akan memberikan keadilan kepada orang-orang yang tertindas, bahkan tidak segan-segan untuk menghajar si penindas. Itulah yang saya sebut sebagai nilai dari keadilan yang dijalankan, yaitu perlindungan kepada yang tertindas. Hal ini sekaligus menjadi sebuah sindiran bagi raja yang memerintah saat itu maupun yang memerintah sebelumnya, yang menjalankan pemerintahan yang memberatkan rakyatnya demi kejayaan pemerintahannya. Raja-mesias yang diharapkan adalah yang dapat memberikan keadilan.

\section{Yesaya 52:13-53:12}

Teks ini dikenal juga sebagai Nyanyian Hamba Tuhan IV yang ada di dalam Deutero Yesaya (DY). Nyanyian Hamba Tuhan ini berisikan pengharapan mesianik bagi umat yang berada di pembuangan. Kontras dengan Yesaya 11:1-10, teks ini menggambarkan sang mesias bukan sebagai raja, tetapi sebaliknya sebagai hamba yang menderita. Keadaannya digambarkan begitu buruk bahkan tidak seperti manusia lagi (52:14), yang oleh Westermann disebut sebagai mewakili situasi manusia yang dijauhi orang karena mengalami penderitaan. ${ }^{5}$ Narasi yang sama disebutkan dalam 53:2, ia "tidak tampan; tidak semarak; tidak ada daya tarik." Penggambaran seperti ini jelas kontras dengan tampilan seorang raja. Dalam PL, sosok raja digambarkan sebagai "yang terelok di antara anak-anak manusia" (Mzm. 45:3). ${ }^{6}$

Kontras antara sang hamba dengan sosok raja yang ideal, sebagaimana dalam Yesaya 11:1-10, dalam penggambaran mesias adalah mewakili ideologi pembuangan. Ideologi RajaSion sudah tidak lagi relevan dengan situasi pembuangan, selain juga dianggap telah menyebabkan pembuangan itu sendiri. Kepercayaan yang berlebihan terhadap kesaklaran Bait Suci dan keistimewaan raja dari dinasti Daud, dituding menjadi penyebab umat menerima hukuman pembuangan. Tentu saja hal itu tidak berarti bahwa ideologi Raja-Sion lenyap sama sekali, tetapi sudah mulai kehilangan popularitasnya dan dipertanyakan. Ideologi yang kental terasa dalam nyanyian ini adalah ideologi Imperium. Jika ideologi Raja-Sion menempatkan Wangsa Daud dalam peran sentral kekuasaan di tengah umat, maka ideologi Imperium memahami kekuasaan mutlak ada di tangan Yhwh dan kemudian la dapat mendelegasikan penguasapenguasa asing untuk kebaikan umat-Nya. ${ }^{7}$ Ideologi ini tidak memepermasalahkan jika pemimpin umat Yahudi mengabdi kepada raja-raja asing. Berkembangnya ideologi ini di periode pembuangan tidak mengherankan menghasilkan keyakinan bahwa Koresh pun, yang adalah raja kafir, disebut juga sebagai mesias (Yes. 45:1) yang diutus Yhwh untuk membebaskan umat yang di pembuangan. Sosok sang hamba yang menderita tersebut oleh beberapa penafsir kemudian dihubungkan dengan Raja Koresh. Namun, saya sendiri tidak melihat ada kecocokan gambaran hamba-mesianik ini dengan Koresh. Menurut saya, sosok ini adalah seseorang yang berasal dari umat Yahudi sendiri, yang pada awalnya dipandang remeh bahkan

\footnotetext{
${ }^{4}$ Walter Brueggemann, Isaiah 1-39 (Louisville: Westminster John Knox Press, 1998), 100.

${ }^{5}$ Claus Westermann, Isaiah 40-66: A Commentary (Pennsylvania: Westminster Press, 1969), 259.

${ }^{6}$ John Goldingay and David Payne, A Critical and Exegetical Commentary on Isaiah 40-55, Volume II. (Edinburgh: T\&T Clark International, 2006), 141.

${ }^{7}$ Gravett et al., An Introduction to the Hebrew Bible: A Tematic Approach, 354.
} 
disingkirkan oleh umat karena dianggap najis, namun kemudian menjadi pemimpin umat, meskipun bukan sebagai raja, ataupun raja dari wangsa Daud.

Karya redemtif yang dilakukan sang mesias adalah untuk menyembuhkan umat dengan menyerahkan dirinya sebagai kurban penebus salah. Mereka yang berada di pembuangan sudah tentu tidak dapat lagi menyelenggarakan ritual pengurbanan. Ketiadaan ritual pengurbanan tersebut dianggap mendatangkan kenajisan bagi umat itu, oleh karena keberadaan ritual kurban dimaknai sebagai kehadiran Yhwh dalam kekudusan-Nya yang juga menjadikan umat menjadi kudus. ${ }^{8}$ Mereka yang di pembuangan, termasuk juga sang hamba ini, dianggap sebagai orang yang kena hukuman Tuhan, karena menurut ideologi Deuteronomik pembuangan adalah hukuman Yhwh atas dosa umat yang memberontak kepada-Nya. Umat yang di pembuangan merasa tidak berdaya, putus asa, dan terhina dengan keadaan mereka sebagai umat pilihan namun hidup di negeri asing. Namun, mereka meyakini bahwa dari mereka jugalah akan bangkit mesias yang memulihkan keadaan umat yang telah najis tersebut. Tentu saja yang dimaksudkan dengan penebusan adalah kembalinya umat ke negeri perjanjian dan dipulihkannya kembali kehidupan masyarakat Yahudi dan ritual ibadah di Bait Suci di negeri perjanjian tersebut.

\section{Yesaya 61:1-11}

Ayat 1-2 dari teks ini merupakan bagian yang terkenal oleh karena dikutip juga oleh Tuhan Yesus sebagaimana yang tertulis dalam Lukas 4:18-19. Ada modifikasi pengutipan dalam Lukas, di mana kalimat "hari pembalasan Allah kita" dihilangkan. Teks ini menyampaikan suatu pengharapan mesianik kepada umat yang tinggal di tanah perjajian pascapembuangan. Sebagaimana ciri khas sebelumnya bahwa tokoh mesianik tidak disebutkan secara jelas, kecuali Koresh, demikian pun dalam teks ini. Namun pada umumnya ada 2 penafsiran terhadap ayat 1-3 mengenai siapakah sosok yang dimaksud. Penafsiran pertama menyebut bahwa sosok tersebut adalah imam. Argumentasinya adalah bahwa 1-3 adalah mencerminkan semangat penebusan tahun Yobel, suatu sistem dalam keimamam (bd. Im. 25). ${ }^{9}$ Penafsiran kedua, sosok tersebut adalah raja. Salah satu pendapat datang dari John H. Eaton, bahwa dalam Festival Tahun Baru, raja biasanya mengumumkan kemenangan Yhwh dan memberitakan kabar gembira sebagaimana yang disebutkan di ayat $2-3 .{ }^{10}$ Saya kira kita bisa menggabungkan kedua kelompok penafsiran tersebut sehingga sosok mesianik tersebut adalah imam sekaligus raja, atau imam yang rajani. Maksudnya, tentu bukan benar-benar menjadi raja, tetapi imam yang memimpin masyarakat, dan bukan hanya mengontrol Bait Suci saja, sebagai pemimpin masyarakat sipil.

Masyarakat Yahudi pasca pembuangan tentu realistis untuk tidak mengharapkan hadirnya raja sebagaimana ketika masih dalam pemerintahan monarki. Mereka kini hanya boleh mengakui satu-satunya raja, yaitu raja dalam kekaisaran Persia. Selain gubernur atau bupati yang diangkat oleh pemerintah Persia, imam menjadi tokoh pemimpin bagi masyarakat sipil. Dengan demikian, pada periode pasca pembuangan terjadi perluasan ideologi Raja-Sion

\footnotetext{
${ }^{8}$ Emanuel Gerrit Singgih, Korban Dan Pendamaian: Studi Lintas IImu, Lintas Budaya, Dan Lintas Agama Mengenai Upaya Manusia Menghadapi Tantangan Terhadap Kehidupan Di Luar Kendalinya (Jakarta: BPK Gunung Mulia, 2017), 100-101.

${ }^{9}$ Pieter De Vries, "Structural Analysis of Isaiah 61 with A Special Focus on Verses 1-3," Old Testament Essays 26, no. 2 (2013): 298-314, accessed May 14, 2021, http://www.scielo.org.za/scielo.php?script=sci_arttext\&pid=S1010-99192013000200006.

${ }^{10}$ Wonsuk Ma, Until the Spirit Comes: The Spirit of God in The Book of Isaiah, ed. David J.A. Clines and Philip R. Davies, JSOT 271. (Sheffield: Sheffield Academic Press, 1999), 122.
} 
yang sebelumnya mesias hanya dipahami dalam sosok raja, maka ideologi dalam periode ini ada dual messaianism. ${ }^{11}$ Pada periode Bait Suci kedua, kekuasaan imam menjadi sangat besar di provinsi Yehuda sehingga mereka muncul sebagai realitas politik yang baru. ${ }^{12}$

Sang mesias diutus untuk memberitakan kabar baik kepada orang-orang yang lemah (anawim) dan merawat orang-orang yang remuk hati (ayat 1b). Istilah anawim itu sendiri mengacu pada orang-orang yang mengalami penindasan secara sosial-ekonomi. ${ }^{13}$ Sedangkan istilah "orang-orang yang remuk hati" (lenisbere-leb) dapat ditemukan juga dalam Mazmur 147:2-3 yang berbicara dalam konteks orang-orang yang tercerai berai. Dengan demikian, misi sang mesias adalah membebaskan orang-orang yang telah kembali dari pembuangan (bene hagolah) dari ketertindasan sosial-ekonomi (bd. Neh. 5).

\section{Rekontekstualisasi Gagasan Mesianik}

Dari ketiga teks mesianik tersebut terlihat bahwa gagasan mesianik bukanlah suatu ide yang beku, sebaliknya itu adalah merupakan ide yang sangat cair, yang selalu mengalami kontekstualisasi sesuai dengan realitas yang dihadapi dan dipergumulkan oleh umat. Tokoh mesianik yang dipikirkan oleh umat pada periode pembuangan ada pada sosok raja yang diharapkan dapat memperbaiki kepemimpinan dalam kerajaan untuk membawa pada kehidupan rakyat yang adil dan penuh dengan damai sejahtera. Berbeda dengan periode monarki, pada periode pembuangan ide raja mesianik mengalami proses demokratisasi oleh karena berhadapan dengan realitas hidup di negeri asing. Figur mesias yang diharapkan boleh datang dari mana saja, bahkan dari raja kafir sekalipun. Yang penting mesias tersebut diharapkan akan menebus mereka dari pembuangan untuk memulihkan kembali martabat sebagai umat pilihan Allah. Pergumulan yang dihadapi pada periode Bait Suci kedua juga berbeda dengan kedua periode sebelumnya. Umat bergumul upaya pembentukan identitas dan restorasi kehidupan kota dan masyarakat. Secara realitis, umat pada periode tersebut mengajukan imam-mesianik sebagai tokoh mesias yang didambakan memimpin mereka mewujudkan visi tersebut.

Ketidakbekuan konsepsi mesias adalah karena konsep tersebut selalu dibawa untuk merespon realitas yang dihadapi. Goran Eidevall menyebut bahwa ada hubungan yang erat antara konsep musuh, ideologi, dan identitas diri. ${ }^{14}$ Dari situ saya dapat mengatakan bahwa konsep musuh mempengaruhi konsep mesias. Bagi kebanyakan orang Kristen, mesias hanya dimaknai sebagai juru selamat yang menebus dosa, yaitu dosa-dosa pribadi yang bersifat moral. Hal ini dikarenakan anggapan satu-satunya musuh dalam hidup adalah dosa pribadi yang dapat menyebabkan kerusakan-kerusakan dalam kehidupan. Akan berbeda apabila kita mulai melihat realitas-realitas masalah dalam kehidupan bersama sebagai musuh yang mana di dalamnya perlu untuk ditebus sehingga memerlukan sosok mesias yang sesuai dengan konteks yang dihadapi. Berkaca dari konsep mesianis yang begitu relevan dengan pergumulan umat sebagaimana yang ditunjukkan dalam kitab Yesaya, maka dalam rangka untuk dapat membumikan gagasan mesianik, sehingga gagasan tersebut dapat berbicara dalam banyak makna dalam kehidupan yang majemuk, maka perlu untuk berangkat terlebih dahulu dari konteks kehidupan bersama sebagai bangsa. Konteks dalam kehidupan bersama tersebut kemudian

\footnotetext{
${ }^{11}$ Gravett et al., An Introduction to the Hebrew Bible: A Tematic Approach, 335.

${ }^{12}$ Ibid.

${ }^{13}$ Martien A. Halvorson-Taylor, Enduring Exile: The Metaphorization of Exile in the Hebrew Bible (Leiden \&

${ }^{14}$ Goran Eidevall, Prophecy and Propaganda: Images of Enemies in The Book of Isaiah (Winona Lake,
} Boston: Brill, 2011), 143-144. Indiana: Eisenbrauns, 2009). 
digumuli secara serius, di mana masalah-masalah yang ada di dalamnya dilihat sebagai realitas yang perlu mengalami karya penebusan. Dari situ kita mulai menggagas konsep mesias yang tepat untuk melakukan karya penebusan tersebut dengan bersumberkan iman dan nilai-nilai Kristiani.

\section{KESIMPULAN}

Kesimpulan dalam makalah ini saya arahkan kepada implikasinya bagi pendidikan teologi khususnya dalam studi PL. Kebekuan konsep mesianis di sebagian kalangan Kristiani sampai saat tidak lain disebabkan oleh pembacaan terhadap teks-teks PL yang selalu dengan menggunakan kacamata Perjanjian Baru (PB). PL yang meskipun diakui memiliki kedudukan yang setara dengan $\mathrm{PB}$, namun pada praktiknya PL dibaca sebagai nubuatan bagi PB, yang artinya secara tidak langsung menganggap bahwa PL belumlah lengkap dan sempurna pada dirinya sendiri. Konsep mesianis yang cair tersebut tidak mungkin didapatkan apabila masih terus membaca PL dalam terang PB. Untuk dapat menemukan kekayaan teologis dan iman dalam PL, maka biarkanlah PL berbicara dari dirinya sendiri, dari konteksnya sendiri, sebagai Firman Tuhan yang sudah lengkap dan utuh tanpa harus menantikan penggenapannya dalam PB. Dari situ studi PL akan dapat didialogkan dengan konteks kehidupan kita dalam berbangsa dan bernegara, oleh karena PL sendiri kaya dengan ideologi-ideologi kebangsaan.

\section{REFERENSI}

Brueggemann, Walter. Isaiah 1-39. Louisville: Westminster John Knox Press, 1998.

Eidevall, Goran. Prophecy and Propaganda: Images of Enemies in The Book of Isaiah. Winona Lake, Indiana: Eisenbrauns, 2009.

Goldingay, John, and David Payne. A Critical and Exegetical Commentary on Isaiah 40-55. Volume II. Edinburgh: T\&T Clark International, 2006.

Gravett, Sandra L., Karla G. Bohmbach, F. V. Greifenhagen, and Donald C. Polaski. An Introduction to the Hebrew Bible: A Tematic Approach. Louisville-London: Westminster John Knox Press, 2008.

Halvorson-Taylor, Martien A. Enduring Exile: The Metaphorization of Exile in the Hebrew Bible. Leiden \& Boston: Brill, 2011.

Ma, Wonsuk. Until the Spirit Comes: The Spirit of God in The Book of Isaiah. Edited by David J.A. Clines and Philip R. Davies. JSOT 271. Sheffield: Sheffield Academic Press, 1999.

Singgih, Emanuel Gerrit. Korban Dan Pendamaian: Studi Lintas IImu, Lintas Budaya, Dan Lintas Agama Mengenai Upaya Manusia Menghadapi Tantangan Terhadap Kehidupan Di Luar Kendalinya. Jakarta: BPK Gunung Mulia, 2017.

Sumner, Stephen T. "The Genealogy and Theology of Isaiah 11:1." Vetus Testamentum 68, no. 4 (September 14, 2018): 643-659. Accessed December 13, 2020. https://brill.com/view/journals/vt/68/4/article-p643_7.xml.

De Vries, Pieter. "Structural Analysis of Isaiah 61 with A Special Focus on Verses 1-3." Old Testament Essays 26, no. 2 (2013): 298-314. Accessed May 14, 2021.

http://www.scielo.org.za/scielo.php?script=sci_arttext\&pid=S1010-99192013000200006.

Westermann, Claus. Isaiah 40-66: A Commentary. Pennsylvania: Westminster Press, 1969. 